\title{
STUDI PENGEMBANGAN EKONOMI KERAKYATAN DI KAWASAN WISATA JAWA TIMUR MELALUI PENGUATAN KELEMBAGAAN SOSIAL EKONOMI MASYARAKAT LOKAL
}

\author{
Khusnul Ashar \\ Bahtiar Fitanto \\ Supartono \\ Fakultas Ekonomi Universitas Brawijaya
}

\begin{abstract}
East Java Province is one of the Indonesia region which high in poverty rate, even higher than national average. One of the effective model to alleviate poverty implemented in developing countries is the model that able to integrate the poor into the tourism sector (Ashley, 2000; Cattarinich, 2001). General aim of this study is to build a proper institution which able to enlarge an opportunities to the poor to become an integral part of the tourism sector. Specific aim of this first year study are: to describe the tourism economic structure in research area of Batu; to describe the relationship intensity between tourism industry and the local economy; to identify the capacity of economic resources of the poor households in term of education level, skills, and capital accessibility; and to identify the social capital and the existence and the nature of local institutions. Analysis unit of this study are : the tourism business unit, the tourists; and the poor household. This study found that: The tourism sector has significance role in the economic structure of Batu. The relationship between tourism industry and local economy is high. Man power, local fruits and vegetable are the main production input for the tourism businesses. Education level of the poor household members is not so low. However, for high level positions in modern tourists industry was mostly filled by people from other area. The role of formal economic institutions such as banks and cooperative business unit in study are not significant for the poor. In order to gain additional capital, the poor mostly rely on the traditional capital accumulation revolving system (Arisan). Beside Arisan, social capital of the poor is also accumulated trough social and religious gathering.
\end{abstract}

Keywords: tourism, local institution

\section{A. LATAR BELAKANG}

Kemiskinan adalah faktor utama penyebab merosotnya kualitas unsur-unsur penyangga kehidupan yang manusiawi. Meningkatnya jumlah anak putus sekolah, melonjaknya angka kriminalitas, merebaknya prostitusi dan AID/HIV, meningkatnya angka kekerasan dalam rumah tangga dan bertambah banyaknya kasus bunuh diri karena himpitan ekonomi, serta rusaknya ekologi sangat dipengaruhi oleh tekanan kemiskinan yang berkepanjangan. Pada konteks wilayah, Propinsi Jawa Timur dewasa ini menunjukkan angka kemiskinan yang sangat memprihatinkan. Ketika angka kemiskinan nasional sudah menunjukkan kecenderungan penurunan dari 17,4 \% menjadi 16,6\% pada periode 2003-2004, angka kemiskinan di Jawa Timur masih bertengger pada angka 20,1\% pada tahun (BPS, 2004).

Salah satu model pendekatan yang terbukti efektif di banyak negara sedang berkembang adalah model pengintegrasian masyarakat miskin dalam industri pariwisata (Ashley, 2000; Cattarinich, 
2001). Model yang belum sempat memperoleh perhatian dari pemerintah ini pada hakekatnya merupakan turunan dari strategi peningkatan pendapatan penduduk miskin melalui pengembangan usaha dan optimalisasi penggunaan sumberdaya manusia. Industri pariwisata yang pada umumnya berada di wilayah pedesaan akan bisa menjadi sarana pengembangan usaha rumah tangga miskin apabila rumah tangga miskin mampu memenuhi kebutuhan barang dan jasa yang diperlukan industri pariwisata atau rumah tangga miskin mampu membuka usaha baru yang bisa memenuhi kebutuhan wisatawan. Industri pariwisata juga akan berfungsi sebagai sarana optimalisasi sumberdaya manusia dari masyarakat miskin apabila anggota keluarga rumah tangga miskin mampu mengisi lowongan kerja yang ada pada industri pariwisata. Dengan demikian, industri pariwisata akan bisa menjadi sarana pengetasan kemiskinan apabila masyarakat miskin bisa menjadi bagian integralnya.

Untuk bisa menjadi penyedia barang-jasa bagi idustri pariwisata; atau menjadi pengusaha kecil pariwisata; atau memperoleh peluang memasuki lowongan kerja di industri pariwisata, kendala pertama yang menghadang masyarakat miskin adalah keterbatasan modal dan ketrampilan. Kendala utama yang lain adalah lemahnya kemampuan mereka dalam menggalang kekuatan kelompok. Pemberian ketrampilan dan permodalan semata bagi orang miskin tidak akan efektif tanpa wahana yang mampu membangun peningkatan nilai tawar (bargaining power) kelompok miskin menghadapi dinamika dan modernisasi industri pariwisata. Harus dimaklumi bahwa masyarakat miskin pada umumnya tidak memiliki institusi yang kuat untuk melakukan berbagai tindakan bersama. Padahal untuk mengoptimalkan fungsi pariwisata sebagai instrumen penanggulangan kemiskinan diperlukan suatu entitas kelembagaan yang merupakan representasi dari masyarakat miskin. Oleh sebab itu perlu dikembangkan suatu kelembagaan yang tepat agar masyarakat miskin disamping bisa memperoleh ketrampilan dan akses modal, mereka juga mampu melakukan negosiasi dan keputusankeputusan strategis dalam rangka memperbesar peluang mereka untuk bisa menjadi bagian dari industri pariwisata. Untuk itulah perlu dilakukan sebuah kaji tindak (action research) yang sistematis dalam rangka membangun suatu kelembagaan pengentasan kemiskinan melalui industri pariwisata berbasis masyarakat lokal.

\section{B. KAJIAN TEORITIS}

\section{Konsep Modal Sosial, Jaringan dan Aspek Budaya.}

Bank Dunia (1999) mendifinisikan Modal Sosial sebagai sesuatu yang merujuk kedimensi institusional, hubungan - hubungan yang tecipta, dan norma - norma yang membentuk kualitas dan kuantitas hubungan sosial dalam masyarakat. Modal sosial bukan sekedar deretan jjumlah institusi atau kelompok yang menopang (underpinning) kehidupan sosial, melainkan dengan spektum yang lebih luas, yaitu sebagai perekat (social glue) yang menjaga kesatuan anggota kelompok secara bersama - sama. Cohen dan Prusak (2001) memberikan pengertian bahwa Modal Sosial sebagai stok dari hubungan yang aktif antar masyarakat. Setiap pola hubungan yang terjadi diikat oleh kepercayaan (trust) saling pengrtian (mutual uderstanding) dan nilai - nilai bersama (shared value) yang mengikat anggota kelompok untuk membuat kemungkinan aksi bersama dapat dilakukan secara efisien dan efektif.

Teori Modal Sosial ini sebenarnya sudah ada sejak Adam Smith dan kawan-kawannya di abad ke 18. Dalam kajian ekonominya, mereka telah memasukkan unsur Modal Sosial dengan jelas, dengan istilah "social contract" yaitu masyarakat sipil yang akan menentukan kemajuan pembangunan ekonomi.

Unsur penting dari "Social contract" ini antara lain apa yang mereka sebut sebagai karakteristik jaringan sosial, pola-pola imbal balik, dan kewajiban-kewajiban bersama. Dari pemikiran-pemikiran kelompok ini pula, beberapa kajian, dan merupakan konsep modern dari modal sosial, di abad berikut memiliki dasar-dasar teoritis yang cukup kuat. Misalnya, apa yang telah dilakukan oleh Marx dan Engles, dengan konsep keterikatan yang memiliki solidaritas (bounded solidarity) yang menggambarkan tentang kemungkinan munculnya pola hubungan dan kerjasama yang kaut. Ketika 


\section{Journal of Indonesian Applied Economics \\ Vol. 3 No. 1 Mei 2009, 10-22}

suatu kelompok berada dalam tekanan negara atau kelompok lain (lihat Woolcock, 1998).

Aspek budaya merupakan salah satu hal penting dalam modal sosial. Hal ini disebabkan aspek budaya terkait dengan ikatan sosial yang ada di masyarakat. Aspek budaya yang didasari ikatan sosial ini sangat penting dalam modal sosial. Lin (2001: 19-20) mengatakan ada 4 (empat) argument yang mendasarinya yaitu:

a. Aliran informasi.

Dalam pasar tidak sempurna ikatan sosial dalan posisi lokasi/hierarki yang strategis dapat menyediakan individu dengan informasi yang berguna tentang kesempatan dan pilihanpilihan.

b. Ikatan sosial

Ikatan sosial dapat memengaruhi pelaku (agents) misalnya supervisor organisasi yang memiliki peran penting (critical role)

c. Ikatan sosial diberikan oleh organisasi atau pelakunya sebagai sertifikasi kepercayaan sosial individu.

d. Hubungan sosial diekspetasikan dapat memperkuat kembali identitas dan pengakuan (recognition).

Modal sosial individu dapat meraih akses langsung terhadap sumber daya ekonomi (pinjaman yang bersubsidi, saran-saran investasi, pasar yang terlindungi). Mereka dapat meingkatkan modal budaya (cultural capital) lewat kontak dengan ahli-ahli atau individu yang beradab (yang melekat dalam modal budaya) atau alternatifnya. Mereka dapat berafiliasi dengan institusi yang membahas nilai-nilai terpercaya (Portes, 1008;3-4).. Sedangkan Dhesi, 2000;210) Uphoff menyatakan bahwa modal sosial dapat ditentukan sebagai akumulasi dari beragam tipe dari aspek sosial, psikologi, budaya, kelembagaan dan asset yang tidak terlihat yang mempengaruihi perilaku kerjasama.

Dalam level yang lebih makro, jembatan modal sosial menurut Erani $(2006 ; 202)$ dapat dikaitkan dengan tata kelola (governance) yang menghasilkan pencapaian ekonomi. Narayan (1999) mengintegrasikan ide inti dari jembatan modal sosial (bridging social capital) yang menyatakan bahwa intervensi yang berbeda dibutuhkan bagi kombinasi tata kelola yang berlainan dan jembatan modal sosial dalam sebuah kelompok, komunitas, atau masyarakat. Pada gambar 1 tampak hubungan antara jembatan modal sosial (bridging social capital) dan tata kelola (governance).

Pendekatan ilmu ekonomi (klasik/neoklasik) menganggap bahwa kelembagaan informal yang hidup dalam struktur sosial tidak memiliki pengaruh tehadap kegiatan ekonomi (investasi, distribusi, konsumsi). Sebaliknya pendekatan ilmu sosiologi menentang asumsi-asumsi rasionalitas materi sebagai desain strategi pembangunan.

Analisis ekonomi yang cenderung sangat kuantitatif dianggap oleh para sosiolog sangat mendangkalkan kompleksitas relasi sosial yang ada di masyarakat, sehingga kebijakan-kebijakan ekonomi yang diproduksi selalu gagal beroperasi. Namun sejak dekade 80-an kesenjangan antara ilmu sosiologi dan ekonomi perlahan mulai dikurangi dengan munculnya konsep/teori modal sosial (social capital). Secara eksplisit, teori modal sosial ini dianggap sebagai perekat potensial untuk menyatukan dua ilmu tersebut.

Teori modal sosial pertama dipicu oleh tulisan Pierre Bourdieu yang dipublikasikan akhir 70an (Fine\& Lapavitsas, 2004; 19). Judul tulisan : La capital Social : Notes Provisoires, diterbitkan dalam "Actes de la Recherche en Sciences Sociales" (1980). Oleh karena publikasi tersebut ditulis dalam bahasa Perancis, maka kurang popular. Setelah James S. Coleman mempublikasikan topik yang sama tahun 1993, mulailah intelektual membahas dan mempertemukan antar disiplin ilmu, sehingga Coleman dianggap sebagai ilmuwan pertama yang memperkenalkan konsep modal sosial seperti yang ditulis dalam jurnal American Journal of Sociology yang berjudul "Social Capital in the Creation of Human Capital" (1988).

Poldan dalam Wallis, Killerlby dan Dolery $(2004 ; 239)$ menyebut modal sosial sangat dekat dengan gabungan bagi seluruh disiplin ilmu sosial (close to becoming a joint concept for all social sciencies). Sebelum diperkenalkannya modal sosial, maka yang lebih terkenal adalah modal manusia dan modal ekonomi (human capital dan economic capital). 
Oleh karena modal ekonomi dan modal manusia dianggap tidak terpengaruh oleh strata sosial alam melakukan kegiatan ekonomi maka hal inilah yang menyebabkan Coleman $(1988 ; 98)$ mendefinisikan modal sosial berdasarkan fungsinya. Menurutnya Modal Sosial bukan entitas tunggal, tetapi entitas majemuk yang mengandung 2 elemen : 1) Modal sosial mencakup beberapa aspek dari struktur sosial 2) Modal sosial mempengaruhi tindakan tertentu dari seseorang, baik secara individu maupun kelompok atau perusahaan. Dengan demikian modal sosial bersifat produktif, yakni membuat pencapaian tujuan tertentu, yang tidak mungkin diraih bila keberadaannya tidak eksis.

\section{Industri Pariwisata dengan Ekonomi Lokal : Konsep Teori dan Temuan Empirik}

Pada tingkat makro, banyak analis setuju bahwa pertumbuhan ekonomi merupakan faktor penting untuk mengurangi kemiskinan. Asumsi Neoliberal telah memandu strategi pengurangan kemiskinan berbasis pertumbuhan dari agensi-agensi bantuan di negara-negara industri dan bank pembangunan multilateral. Underhill (dalam Cattarinich, 2001) mempuyai premis bahwa interaksi bebas antara individual sebagai agen ekonomi akan memaksimumkan kesejahteraan sebesar-besarnya pada populasi global. Beberapa analis menyatakan bahwa pertumbuhan akan jadi lebih baik bagi kaum miskin apabila:

- padat karya, terutama tenaga kerja yang tak punya keahlian

- terjadi pada orang miskin dan area terisolir.

- terjadi di pedesaan, agrikultur, dan sektor jasa/layanan kecil-kecilan.

Sebagai tambahan, menurut ODI dan AIRD (dalam Cattarinich, 2001) pertumbuhan pro-poor tourism tergantung pada suatu distribusi asset yang ada, terutama dalam kaitannya dengan lahan (SDA) dan modal manusia (SDM).

Menurut Carney (dalam Cattarinich, 2001) ditingkat ekonomi mikro sektor pariwisata dapat mengurangi kemiskinan dengan pendekatan mata pencaharian berkesinambungan. Dimana sektor pariwisata menekankan kepada perlunya partisipasi masyarakat lokal dan kesesuaian antara strategi pengembangan sektor pariwisata dengan mayoritas mata pencaharian masyarakat miskin disekitar tempat pariwisata, dengan cara membangun aset orang-orang miskin dan pengembangan keterbatasan lingkungan. Terkait dengan hal itu, pariwisata untuk menjadi suatu strategi pengurangan kemiskinan yang efektif, dengan memberikan tambahan mata pencarian bagi masyarakat miskin dengan menyediakan suatu kesempatan untuk penganeka-ragaman ekonomi tanpa mengganggu atau mengganti/ menggantikan mata pencarian itu (Ashley dalam Cattarinich, 2001). Pantas tidaknya pariwisata sebagai strategi pro-poor tourism yang dengan jelas akan terjadi hubungan timbal balik ekonomi antara kepentingan lingkungan dan sosial. Negara-Negara tertentu juga memandang pariwisata skala kecil mempunyai potensi lebih besar untuk meningkatkan multiplier lokal dengan penambahan mata rantai dengan pertanian dan lain sektor ( Forsyth dalam Cattarinich, 2001).

Kegiatan pariwisata akan berpengaruh langsung dan tidak langsung terhadap masyarakat setempat, pengaruh langsung dalam pariwisata ini dapat dikelompokkan menjadi : akomodasi, transportasi, makanan dan restaurant, dan pelayanan rekreasi (Shuib et al, 1986 dalam Stecker, 1986). Sehingga masyarakat setempat akan mendapatkan pendapatan dan lapangan kerja dari kegiatan ini. 


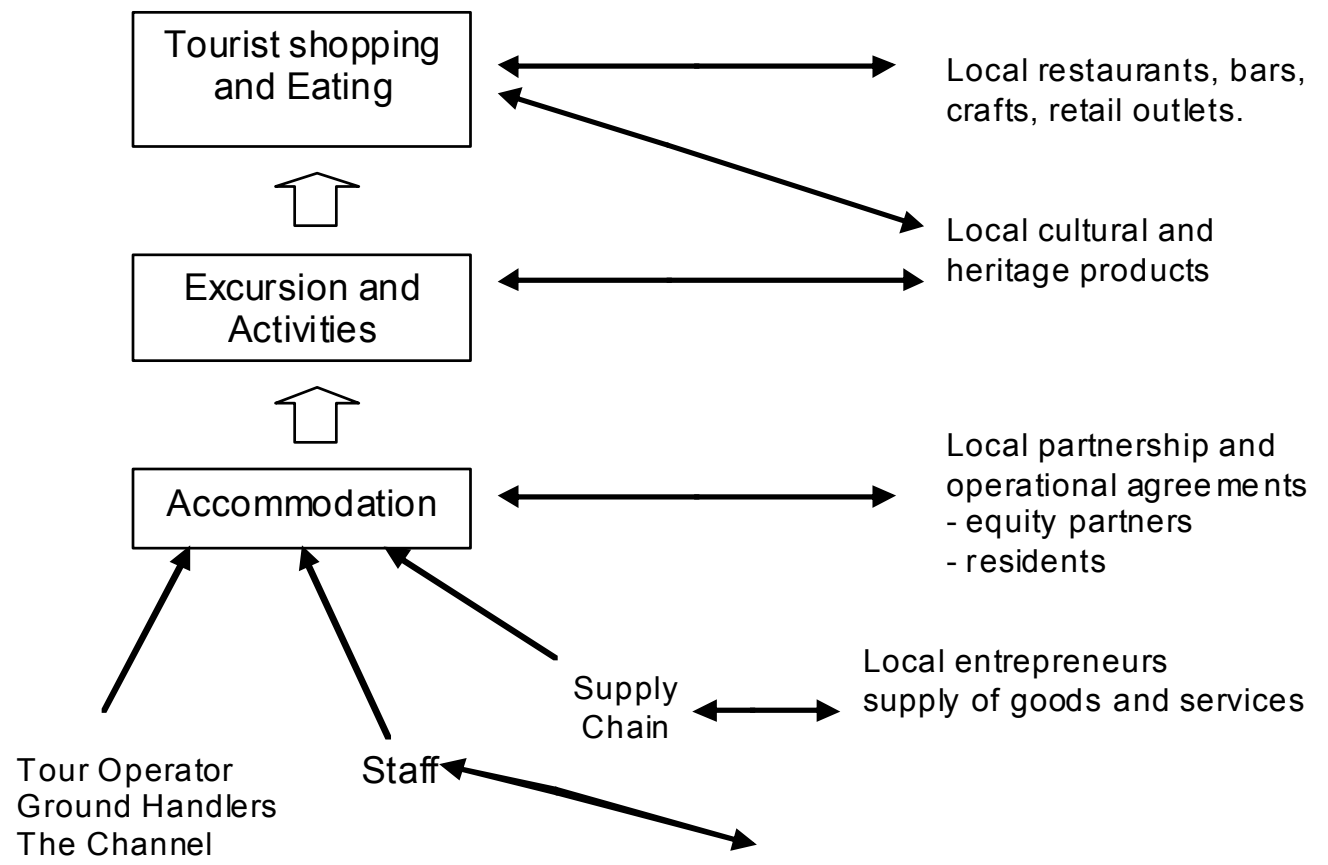

Source : Ashley et al, 2006

Gambar 1. Pola Keterkaitan Antara Pariwisata dan Ekonomi Lokal

\section{Peranan Pariwisata Terhadap Masyarakat Miskin.}

Pariwisata Memberikan Peluang Yang Luas BagiRumah Tangga Miskin( RTM).

Beberapa buah pariwisata berbasis masyarakat mempunyai sasaran kunci di luar konservasi lingkungan alam dan warisan budaya, Pro Poor Tourism (PPT) membutuhkan lebih dari sekedar fokus komunitas. Menurut DFID (dalam Cattarinich, 2001), Pariwisata pro orang miskin menghasilkan keuntungan bersih bagi orang miskin. Keuntungan ekonomi hanya satu komponen saja - biaya dan keuntungan sosial, dan lingkungan juga perlu diperhatikan

Strategi pariwisata pro orang miskin terkait secara rinci dengan dampaknya pada orang-orang miskin, meskipun yang tidak miskin juga mendapat manfaatnya. Keuntungan ekonomi hanya satu yang sangat penting yaitu sosial, lingkungan, budaya. Strategi pariwisata pro orang miskin memperhatikan secara lebih khusus dampaknya pada orang miskin meskipun yang tidak miskin juga mendapat manfaatnya. Strategi fokus pada sedikit berkembangnya ukuran pariwisata tapi lebih pada membuka peluang untuk kelompok tertentu. ( DFID, dalam Cattarinich, 2001)

Suatu organisasi mencoba ke strategi operasional di tujuan tingkatan yang mungkin menyediakan ketenaga-kerjaan atau tenaga kerja kepada orang miskin, hal ini bisa menetapkan pertalian persediaan dengan petani atau para pedagang dari orang miskin dan menghasilkan beberapa jasa ( seperti penatu), program acara pelatihan, atau usaha patungan dengan masyarakat, dan beberapa pilihan lainnya.

Suatu tinjauan ulang riset pariwisata di Asia melaporkan bahwa kebanyakan studi kasus, ada keuntungan ekonomi untuk bagian masyarakat yang lokal, ( Shah Dan Gupta dalam Cattarinich, 2001). Ketika manfaat yang diterima orang miskin dari pariwisata pada umumnya sebagai penjual keliling atau penjaja di jalan atau tenaga kerja rendahan ( seperti kuli pengangkut barang atau asisten ' tingkat rendah' di hotel, pondokan, dan organisasi tour) ( Shah Dan Gupta, dalam Cattarinich, 2001).

Shah dan Gupta dalam Cattarinich, 2001 menyatakan bahwa pariwisata berguna untuk membedakan antara keikutsertaan di sektor formal ( seperti hotel), sektor informal ( seperti penjual 
keliling, berperahu) dan didalam perusahaan sekunder yang mempunyai pertalian ( seperti persediaan makanan).

\section{Peranan Pariwisata Dalam Penambahan Mata Pencaharian RTM}

Pendekatan mata pencaharian yang bisa mendukung, menekankan kebutuhan akan keikutsertaan masyarakat lokal dan kecocokan antar strategi, mata pencarian orang miskin, berdasar pada asset orang miskin dan pembatasan lingkungan (Carney dalam Cattarinich, 2001). Seperti itu, karena pariwisata untuk menjadi suatu strategi pengurangan kemiskinan efektif, melengkapi mata pencarian yang ada untuk orang miskin dengan menyediakan suatu kesempatan untuk penganeka-ragaman ekonomi tanpa mengganggu atau menggantikan mata pencarian itu (Ashley dalam Cattarinich, 2001). Jika biaya-biaya kepada orang miskin ( apakah ekonomi, sosial, atau lingkungan) dalam keikutsertaan didalam pariwisata lebih besar dibanding manfaatnya, maka itu bukanlah suatu strategi pro-kemiskinan yang sesuai. Pantas tidaknya pariwisata sebagai strategi pro-orang miskin dengan jelas akan bertukar-tukar dengan konteks lingkungan dan sosial.Negara-Negara tertentu juga memandang pariwisata skala kecil mempunyai potensi untuk meningkatkan multiplier lokal dengan penambahan mata rantai dengan pertanian dan lain sektor (Forsyth, dalam Cattarinich, 2001). Lebih dari itu, pariwisata skala kecil cenderung untuk mengurangi ketidakmerataan mengenai ruang melalui peredaran perusahaan lebih luas. Dalam teori, merangsang mobilitas wisatawan dan suatu lebih pada distribusi pembelanjaan wisatawan (Brohman, 1996, dalam Cattarinich, 2001).

\section{Keterlibatan Wanita RTM Dengan Pariwisata}

Pariwisata memberikan sumbangan pada pengurangan kemiskinan dengan penyediaan lapangan pekerjaan, peluang untuk meningkatkan pendapatan dan juga pengurangan kerentanan. Lebih khusus lagi, pariwisata memberikan sumbangan secara efektif pada pembangunan berkesinambungan dan pengurangan kemiskinan dengan sejumlah cara khusus antara lain dengan mendorong persamaan gender di dalam peluang kerja. (Damanik, 2005)

Dari segi pandangan empiris, suatu evaluasi komparatip terbaru dari kebijakan donor dan efektivitas dari proyek mereka di negara berkembang menunjukkan bahwa intervensi sukses akhirnya tergantung pada empat unsur-unsur berikut: sasaran yang sesuai/ tepat, kepekaan jenis kelamin, keikutsertaan, dan keberlanjutan(Cox dan Healey, dalam Cattarinich, 2001).

Ada beberapa bukti dimana pariwisata lebih padat karya dibanding pabrikasi dan mempekerjakan wanita-wanita dengan proporsi yang tinggi. Mengenai peran wanita-wanita dalam pariwisata, Shah Dan Gupta dalam Cattarinich 2001, menulis bahwa menemukan kebanyakan peluang wanitawanita di sektor yang informal, dengan aktivitas berkisar antara koleksi dan penjualan kayu bakar dan membawa beban dari road-heads, ke toko dan kerajian tangan [teashops] dan mengatur pesanggrahan menurut cara mereka sendiri' .

Walaupun kebanyakan wanita miskin cenderung mendapat dampak negatif dari pariwisata seperti di Mangali Negeri Nepal. (Shah Dan Gupta, dalam Cattarinich, 2001). Semua permasalahan ini harus ditujukan dalam urutan untuk pariwisata untuk menjadi pro-orang miskin.

\section{Dampak Ganda (Multiplier Effect) Pariwisata}

Sektor pariwisata bukanlah sector yang berdiri sendiri. Sektor pariwisata berkaitan secara langsung dan tak langsung dengan berbagai sektor perekonomian yang memproduksi barang-barang dan jasa-jasa yang sebagian atau seluruhnya dikonsumsi oleh wisatawan, baik itu wisatawan mancanegara maupun wisatawan nusantara. Dengan demikian berarti pertumbuhan sektor pariwisata dapat dianggap sebagai pendorong laju pertumbuhan sektor-sektor lain termasuk pertanian. Dampak ekonomis pariwisata yang lintas sector ini bahkan juga melintas multi sector dalam bentuk, pemerataan, pendapatan, kesempatan kerja dan investasi. Pariwisata dalam proses pengembangannya mempunyai dampak yang tidak sama pada daerah atau wilayah yang berbeda. Hal itu terlihat baik dalam lingkup yang besar seperti dalam lingkup negara yaitu antara negara berkembang dengan 


\section{Journal of Indonesian Applied Economics \\ Vol. 3 No. 1 Mei 2009, 10-22}

negara maju, atau dalam lingkup yang lebih sempit yaitu dalam lingkup wilayah/propinsi dalam suatu negara.

Perbedaan dampak antar daerah belum tentu merugikan. Bahkan dapat berperan penting dalam mengurangi ketimpangan kerja dan ketimpangan pendapatan antar daerah di dalam suatu Negara. Bukankah kerap kali obyek dan daya tarik wisata terutama wisata alam umumnya terletak jauh dari pusat aktivitas perekonomian. Pengurangan tingkat ketimpangan ini dimungkinkan karena aktivitas pariwisata memiliki karakteristik yang tidak dimiliki kegiatan di sektor lain. Konsumenlah yang datang ke produsennya, untuk membelanjakan uangnya pada berbagai barang dan jasa yang ditawarkan masyarakat di daerah wisata. Saat ini jenis kegiatan yang terkait dengan pariwisata serta dampak yang diciptakan, belum diidentifikasi secara jelas dan masih terus menjadi pembicaraan. Karena ketidakjelasan ini boleh jadi suatu kebijakan atau analisis ekonomi sektoral yang berhubungan dengan kepariwisataan dapat tumpang tindih, atau terlewat untuk diperhitungkan. Hal ini dapat berdampak pada dikeluarkannya kebijakan yang kurang peka dan boros serta analisis yang kurang tajam. Selama ini kajian dan analisis hasil pembangunan kepariwisataan baru mencakup sebagian aspek dan dilakukan secara terpisah-pisah. Demikian juga metodologi dan indikator yang digunakan masih sederhana, sehingga hasilnya saling tidak konsisten serta kurang akurat. Sudah tentu bila diaplikasikan ke dalam perumusan kebijakan, akan menghasilkan kebijakan yang kurang tajam dan tidak menyeluruh.

Konsep Dampak Ganda didasarkan pada hubungan berbagai sektor pembentuk ekonomi yang saling terkait serta memiliki ketergantungan dalam ekonomi lokal.. Oleh karenanya, setiap perubahan pada tingkat pengeluaran wisatawan, sebagai salah satu sektor pembentuk ekonomi, akan mempengaruhi industri barang dan jasa, Setiap perubahan seperti pengeluaran wisatawan berpengaruh terhadap tingkat pengeluaran (output), nilai tambah, upah / gaji, ketenagakerjaan (employment), penerimaan negara (government revenue),dan neraca pembayaran. Rasio perubahan dalam setiap variabel diatas terhadap perubahan dalam permintaan akhir (dalam hal ini pengeluaran wisatawan) disebut multipllier. Kompleksitas dari analisis pengganda tergantung dari seluk beluk transaksi yang terdapat pada sektor ekonomi di tiap daerah. Pariwisata mempunyai kompleksitas yang tinggi karena keterkaitannya dengan banyak sector ekonomi,.seperti akomodasi/hotel, restoran, tranportasi, jasa hiburan dan rekreasi serta cinderamata. Dampak yang ditimbulkan sector pariwisata dapat dibagi menjadi tiga yaitu dampak langsung (direct effect), dampak tak langsung (indirect effect) dan dampak ikutan (induced effect). Pada dampak langsung, dampak outputnya akan sama dengan nilai perubahan pada permintaan akhir. Pengeluaran wisatawan secara langsung akan menimbulkan pendapatan bagi industri pariwisata seperti hotel, restoran usaha kerajinan, Perkembangan kunjungan wisatawan secara otomatis merupakan pertumbuhan industri pariwisata. Sedangkan dampak tak langsung mengacu pada kelanjutan dari kebutuhan sebuah industri yang mengalami peningkatan permintaan produknya untuk melakukan pembelian dari industri lain yang terkait. Misalnya hotel yang mendapat tamu wisatawan akan membayar gaji atau membeli barang keperluan hotelnya dari pedagang alat rumah tangga. Permintaan dari hotel ini merupakan derivative demand yang tidak berhenti pada pedagang saja tetapi akan terus berlanjut samapi industri hulunya. Dampak ikutan terjadi karena peningkatan pendapatan akibat peningkatan permintaan akhir sebagian akan dibelanjakan untuk konsumsi barang dan jasa yang tidak berkaitan dengan permintaan akhir tersebut. Penjual souvenir akan membelanjakan sebagian pendapatannya untuk memperbaiki rumah, menyekolahkan anak, membeli barang elektronik dan sebagainaya. Makin banyak yang dibelanjakan oleh industri pariwisata dan industri terkait untuk berbagai jenis barang dan jasa , makin besar dampak ikutan dari sector pariwisata. Pemasok barang dan jasa akan meningkat pendapatannya, Peningkatan pendapatan ini akan mendorong lebih lanjut perekonomian masyarakat sehingga kesempatan kerja dan pendapatan makin lama makin meningkat. 


\section{METODE PENELITIAN DAN ANALISIS DATA}

\section{Lokasi Penelitian dan Unit Analisis}

Lokasi penelitian kaji tindak ini adalah kawasan wisata pegunungan di Kota Batu Jawa Timur. Pilihan atas obyek wisata di wilayah ini adalah disesuaikan dengan kondisi sosial-budaya mayoritas kaum miskin di Jawa Timur yang sebagian besar bermata pencaharian sebagai buruh tani dan pedagang kecil. Kawasan wisata di kota Batu didominasi oleh wisata agro yang erat kaitannya dengan mata pencaharian kaum miskin yang pada umumnya berada disub sektor budidaya tanaman hias dan holtikultura. Disamping itu sebagian kaum miskin diwilayah kota Batu dan sekitarnya banyak yang mencari nafkah dibidang usaha kerajinan-souvenir (handy craft) sebagai pendukung kegiatan wisata agro.

Unit analisis kaji tindak ini terdiri atas tiga pelaku dalam industri pariwisata yaitu, uaitu unit usaha pariwisata (Jatim Park dan Pemandian Tirta Nirwana), wisatawan, dan rumah tangga kurang mampu ( pedagang kecil di lokasi pasar wisata Songgoriti).

\section{Sampel dan Teknik Sampling}

Untuk unit analisis usaha wisata, sampel yang diambil adalah Jatim Park dan Pemandian Tirta Nirwana. Pilihan pada Jatim Park adalah karena obyek wisata ini menurut data BPS-Batu merupakan kawasan wisata Batu yang paling banyak dikunjungi oleh wisatawan. Dengan demikian ia mewakili obyek wisata yang dominan di Batu. Sedangkan pilihan terhadap pemandian Tirta Nirwana adalah dengan alasan bahwa kawasan ini merupakan kawasan wisata khas Batu karena disamping menyediakan panorama pegununngan, juga terdapat wahana wisata berupa sumber air panas.

Untuk unit analisis wisatawan, sampel yang diambil adalah para wisatawan yang berada di kawasan Songgoriti. Pilihan pada lokasi ini dengan pertimbangan tidak terdapat perbedaan yang menyolok antara karakteristik wisatawan di Songgoriti dengan wisatawan di lokasi lain di Batu.

Untuk unit analisis rumah tangga miskin, sampel yang diambil adalah para pedagang di pasar wisata pemandian Tirta Nirwana Songgoriti. Pilihan pedagang kecil adalah dengan pertimbangan bahwa sektor perdagangan khususnya di pasar-pasar wisata merupakan sektor ekonomi yang menjadi mediator utama antara rumah tangga miskin produsen kerajinan, makanan, sayur dan buah dengan industri pariwisata khususnya wisatawan yang menjadi konsumennya. Pilihan pedagang kecil di lokasi pasar wisata Songgoriti adalah dengan pertimbangan bahwa pasar wisata yang terletak didekat pemandian Tirta Nirwana adalah pasar kecil yang pada umumnya diisi oleh pedagang skala mikro (berbeda dengan pasar wisata Jatim Park dan Selecta yang bersifat eksklusif, hanya bisa diisi oleh para pedagang dengan modal yang lebih besar karena tarif sewa stand dengan cukup mahal).

Dengan demikian teknik sampling yang digunakan dalam memperoleh sampel rumah tangga kurang mampu dan wisatawan adalah dalam katagori Non Probability Sampling yang dalam hal ini teknik yang digunakan adalah Accidental Sampling yaitu pedagang dan wisatawan mana saja yang bisa ditemui di dalam area pasar wisata Songgoriti.

Teknik sampling yang digunakan adalah Purposive Sampling yaitu pengabilan sampel yang diambil secara sengaja guna memperoleh sampel yang diperlukan.

\section{Metoda Analisis}

Analisis data dalam penelitian dilakukan melalui tiga tahapan, yaitu:

1. Reduksi data, dimana reduksi data ini akan dilakukan bersamaan dengan proses pengumpulan data sampai dengan selesai.

2. Analisis domain, peneliti akan mengkatagorikan berbagai ungkapan dan realitas sosialekonomi yang diperoleh secara sistematis.

3. Pembuatan kesimpulan, verifikasi, dan refleksi. Pada proses ini peneliti melakukan interpretasi terhadap makna dari data empiris yang telah dikumpulkan dan dikategorikan sebelumnya secara sistematis. Proses verifikasi berlangsung berulang dan dinamis dalam berbagai situasi 


\section{Journal of Indonesian Applied Economics \\ Vol. 3 No. 1 Mei 2009, 10-22}

praktis di lapangan, dan ini dilakukan atas informasi lisan maupun dokumentasi. Proses refleksi dilakukan untuk mendapatkan pemahaman yang benar dan utuh atas ucapan dan makna dibalik ucapan tersebut menjadi titik kritis dalam penelitian ini.

\section{HASIL DAN PEMBAHASAN}

\section{Keterkaitan Industri Pariwisata dengan Ekonomi Lokal}

Struktur ekonomi pariwisata di kota Batu menunjukkan pentingnya peranan sektor pariwisata dalam perekonomian daerah yang nampak pada besarnya kontribusi sektor ini terhadap PDRB kota Batu. Karakteristik obyek wisata yang ada berbasis pada keindahan alam khususnya agrowisata yang dikombinasikan dengan wisata buatan untuk meningkatkan fungsi-fungsi hiburan bagi seluruh segmen wisatawan ( tua, muda dan anak-anak ). Keberadaan Jatim Park, Songgoriti, Hotel, Restoran dan Pasar Wisata merupakan unit-unit usaha yang memberi kontribusi nyata bagi Pendapatan Asli Daerah dan ekonomi lokal.

Hubungan antara industri pariwisata dengan ekonomi lokal sangat erat. Sarana produksi tenaga kerja, sayur-buah lokal menjadi input utama dari unit-unit industri pariwisata yang ada. Sektor perdagangan khususnya di pasar-pasar wisata merupakan sektor ekonomi yang menjadi mediator antara rumah tangga miskin produsen handy-crafts, kripik, tanaman hias, sayur dan buah dengan wisatawan. Jatim Park merupakan objek parawisata yang memadukan secara serasi antara konsep pendidikan dan konsep pariwisata dalam satu ruang dan satu waktu, sehingga mampu memberikan informasi kepada masyarakat untuk dapat lebih mengenal budaya bangsa sekaligus menambah khasanah ilmu pengetahuan dan teknologi.

Lokasi Jawa Timur Park terletak di di lereng timur gunung Panderman yang dibangun diatas area seluas kurang lebih 7 hektar, walaupun tidak luas namun diusahakan lengkap dalam sajian wisatanya. Pada kawasan yang sejuk dan asri, Jawa Timur Park memadukan tempat rekreasi dengan dunia ilmu pengetahuan dan teknologi. Fasilitas yang ditawarkan di Jawa Timur Park diberikan dengan suguhan "one stop service", dengan berbagai macam fasilitas kepada pengunjung, berupa :

Fasilitas Pembelajaran berupa taman belajar lengkap dengan peragaan iptek, sejarah, dan traditional knowledge, insektarium, animal diorama, baby Zoo, taman burung, taman reptile, dan taman ikan. Keseluruhan fasilitas pembelajaran ini menempati $30 \%$ dari keseluruhan area. Fasilitas rekreatif yang berhubungan dengan unsur permainan dan hiburan, yang menempati $30 \%$ dari keseluruhan area. Fasilitas pendukung, berupa outlet-outlet makanan dan minuman seperti food centre, restaurant dan cafe, galeri seni dan souvenir, pasar buah, sayur, dan hewam, serta . Kawasan ini menempati $20 \%$ dari keseluseluruhan area. Fasilitas umum berupa tempat parkir, mushola, open teater, dan toilet. Kawasan ini menempati 20\% dari keseluruhan area.

Industri Pariwisata sangat berhubungan dengan pertumbuhan ekonomi lokal, terutama dalam bidang penyerapan tenaga kerja. Jawa Timur Park berperan dalam penyerapan tenaga kerja lokal di Kota Batu sekitar 65\% karyawannya berasal dari penduduk di wilayah Kota Batu. Sedangkan dari luar Kota Batu yaitu 25\% yang sebagian berasal dari Kota Malang sedangkan lainnya dari daerah lain .

Tingginya prosentase jumlah karyawan yang berasal dari Kota Batu membuktikan bahwa industri pariwisata yang ada dapat mengurangi tingkat pengangguran. Selain itu dalam pembentukan PDRB Kota Batu, industri pariwisata berperan paling besar mencapai 68,55\% pada tahun 2006 dan besarnya pekerja yang bekerja di sektor jasa ini mencapai 46,32\% (Data BPS Kota Batu).

Banyaknya tenaga kerja yang berasal dari kota Batu tidak diimbangi dengan tingginya tingkat sumber daya manusia nya yang bagus pula, terbukti dari adanya level/ posisi karyawan dalam struktur tenaga kerja, bila di lihat dari 3 level dari jumlah 223 pekerja yaitu:

- High Manager : 3 orang, 1 berasal dari Kota Batu

- Middle Manager : 150 Staff, rata-rata berasal dari Kota Batu

- Lower Manager : : 70 staff, semua berasal dari Kota Batu

Dari level tenaga kerja diatas dapat disimpulkan bahwa las an mengapa banyak karyawan yang 
merupakan penduduk asli Kota Batu berada di level Middle dan Lower Manager, dikarenakan keterbatasan Sumber Daya Manusia dan rendahnya tingkat dan mutu pendidikan masyrakatnya. Dapat diketahui dari pendidikan terakhir yang ditempuh, banyak karyawan Jawa Timur Park yang mempunyai pendidikan terakhir SMA dan sebagian ditempatkan dilevel middle manager dan kebanyakan di level Lower Manager. Tingkat upah karyawan di Jatim Park masih sesuai dengan UMR (Upah Minimun Regional) Kota Batu, yaitu sebesar Rp. 737.000 belum termasuk tunjangan dan bonus.

Di Tirta Nirwana, Songgoriti, total pekerja berjumlah 35 orang yang semuanya berasal dari tenaga kerja kota batu yang terdiri dari pekerja kontrak dan honorer, dalam tirta nirwana ini tidak ada level tenga kerja. Karena milk swasta jadi management mutlak berada dipimpinan.

Tingkat pendidikan tenaga kerja di tirta nirwana songgoriti rata - rata pendidikan terakhrirnya SD dan SMP yang diutamakan yang mempunyai keterampilan ( Potong rumput, siram tanaman, kebersihan dll) dan semuanya berasal dari kota batu dan dikhususkan diwilayah songgoriti. Termasuk para mandor sebagai wakil pimpinan dan mandor inilah yang memiliki tingkat pendidikan tertinggi, yaitu lulusan SMA.Tingkat upah tenaga kerja di tirta nirwana songgoriti masih mengikuti UMR sekitar Rp600.000 - Rp700.000 dan upah tertinggi diperoleh mandor yaitu Rp1.000.000 Rp1.300.000. PT Tirta Nirwana ini juga mengelola beberapa restoran yang menggunakan bahan bahan dari kota batu, para pedagangya merupakan beberapa warga yang berada dikota batu.

Wisatawan di Batu sebagain besar (90\% lebih) berasal dari luar Batu, paling banyak berasal dari kota lain di Jawa Timur. Pada umumnya tidak menginap, $60 \%$ mengunjungi Batu lebih dari 3 kali pertahun, oleh-oleh yang mereka beli di Batu utamanya adalah buah, aneka kripik, sayur dan tanaman hias.

\section{Kapasitas SDM rumah tangga kurang mampu}

Dilihat dari pendidikannya relatif memadai, sebagain besar $(72,5 \%)$ berusia produktif dibawah 40 tahun. Sebesar 60,00\% responden berada pada kelompok umur 25-40 tahun, yaitu kelompok umur produktif. Jumlah terbesar kedua adalah kelompok umur 41-60 tahun yaitu 25,00\%, secara umum cukup produktif. Dari 40 responden yang berusaha secara mikro terdapat $12,50 \%$ berusia kurang dari 25 tahun. Secara keseluruhan responden masih amat produktif dalam menjalankan kegiatannya Namun demikian, untuk jabatan pimpinan di usaha pariwisata modern masih lebih banyak (sekitar 70\%) diisi oleh tenaga kerja dari luar Batu.

Usaha yang dijalankan relatif cukup lama. $45,00 \%$ responden menjalankan usahanya lebih dari 5 tahun sampai 10 tahun. Sejumlah 40,00\% responden menjalankan usaha mikronya lebih dari 10 tahun. Sedangkan hanya $15,00 \%$ saja yang menjalankan usahanya kurang dari 5 tahun. Data ini juga menggambarkan bahwa responden cukup lama menekuni usahanya. Satu dan lain hal berarti cukup memberikan dukungan dalam mengembangkan potensi untuk berkembang dan mempunyai dampak positif yaitu melepaskan diri dari kekurang mampuan ekonomi rumah tangganya.

Tabel 1. Prosentase Responden Menurut rata-rata Pendapatan Pada musim Liburan dan Hari Biasa

\begin{tabular}{|c|c|c|c|}
\hline \multirow[t]{2}{*}{ No } & \multirow{2}{*}{$\begin{array}{c}\text { Rata-Rata Pendapatan } \\
\text { Harian }\end{array}$} & Prosentase & \multirow{2}{*}{$\frac{\text { Prosentase }}{\text { Hari-Hari Biasa }}$} \\
\hline & & Musim Liburan & \\
\hline 1 & $<\mathrm{Rp} 50.000$ & 0,00 & 27,50 \\
\hline 2 & $\mathrm{Rp} 50.000-\mathrm{Rp} 100.000$ & 2,50 & 37,50 \\
\hline 3 & $\mathrm{Rp} 101.000-\mathrm{Rp} 200.000$ & 12,50 & 17,50 \\
\hline 4 & $\mathrm{Rp} 201.000-\mathrm{Rp} 300.000$ & 5,00 & 7,50 \\
\hline 5 & $\mathrm{Rp} 301.000-\mathrm{Rp} 400.000$ & 7,50 & 2,50 \\
\hline 6 & $\mathrm{Rp} 401.000-\mathrm{Rp} 500.000$ & 20,00 & 5,00 \\
\hline 7 & $\mathrm{Rp} 501.000-\mathrm{Rp} 1.000 .000$ & 37,50 & 0,00 \\
\hline \multirow[t]{2}{*}{8} & $>\mathrm{Rp} 1.000 .000$ & 15,00 & 2,50 \\
\hline & Tota 1 & 100,00 & 100,00 \\
\hline
\end{tabular}

Sumber : data primer diolah 


\section{Journal of Indonesian Applied Economics \\ Vol. 3 No. 1 Mei 2009, 10-22}

Pendapatan responden menujukkan fluktuasi yang nyata antara musim libur dengan hari-hari biasa dimana ada hari-hari libur tingkat pendapatan yang relatif tinggi. Pada hari-hari libur sebagian besar responden mempunyai omset penjualan rata-rata lebih dari Rp 300.000,- per hari. Sedangkan pada hari biasa omset sebagian besar mereka kurang dari Rp 200.000,- (lihat tabel 1)

Hal ini menunjukkan hubungan yang kuat antara kegiatan responden dengan jumlah wisatawan yang datang ke daerah penelitian. Kawasan wisata ini memberikan sumbangan yang cukup berarti bagi responden maupun wisatawan. Pada hari-hari libur tingkat pendapatan responden tidak kecil. Berdasarkan pemantauan dan observasi serta wawancara secara langsung diperoleh data, bahwa yang dimaksud hari-hari libur disini terutama pada hari libur jangka panjang pada hari-hari sekolah. Sebagai contoh liburan akhir semester genap menjelang awal semester ganjil atau awal tahun ajaran baru. Contoh yang lain liburan hari raya lebaran, tahun baru, dan sebagainya. Informasi cukup penting yaitu bahwa pada hari-hari libur dan hari biasa, responden masih memperoleh pendapatan lebih dari Rp.1.000.000 yaitu $15,00 \%$ pada hari libur dan 2,50\% pada hari biasa. Hal ini menunjukkan, bahwa tidak pernah terjadi masa sulit bagi responden dengan usaha mikronya.

\section{Modal Sosial}

Dari data primer yang diolah, nampak bahwa modal sosial yang dimiliki oleh pedagang kecil cukup besar, hubungan yang erat sesama mereka memungkinkan penyediaan tambahan modal usaha bisa diperoleh melalui system arisan. Di daerah penelitian memang sudah terdapat lembaga keuangan formal penyedia pinjaman modal seperti koperasi dan bank; namun dari total responden pedagang kecil hanya $35 \%$ yang pernah berhubungan dengan koperasi dan hanya $24,39 \%$ yang pernah meminjam modal dari bank. Hampir seluruh responden yang diwawancarai ( $90 \%$ ) menyatakan ikut arisan sebagai wahana penyedia modal. Besarnya peranan arisan bisa juga dilihat dari pengakuan responden ketika ditanyakan sumber pinjaman modal selain koperasi. Dari jawaban responden, hanya $14,63 \%$ yang mengaku pinjam dari saudara/famili dan hanya $2,44 \%$ yang meminjam dari teman. Fakta ini membuktikan bahwa mereka merasa lebih cocok dengan system arisan dalam memenuhi kebutuhan permodalan dari pada lembaga keuangan formal (Bank atau Koperasi) maupun sumber modal informal (teman atau saudara).

Kecocokan dengan kelembagaan yang bersifat informal, terbuka dan aspiratif sesuai kebutuhan responden semakin jelas bila dilihat dari partisipasi responden pada kegiatan sosial rutin seperti Yasinan, Pengajian, Kesenian dsb. Pada tabel 17 nampak bahwa dari total responden, hanya 6,15\% yang tidak aktif mengikuti kegiatan sosial. Pada table tersebut, 32,31\% responden secara rutin mengikuti Yasinan, 23,08\% mengikuti Pengajian, 33,85\% ikut kegiatan Tahlilan, Istighosah, Hiking, PKK, Posyandu, dan kegiatan Gereja.

\section{E. KESIMPULAN DAN REKOMENDASI}

\section{Kesimpulan}

1. Pada umumnya usaha kecil masih memerlukan tambahan modal, namun mereka enggan memenuhinya melalui lembaga keuangan formal seperti Bank, Koperasi. Mereka juga tidak terlalu mengandalkan bantuan modal dari saudara atau teman.

2. Peranan lembaga lokal formal seperti Koperasi dan Bank relatif kecil. Modal sosial yang dipupuk dan menjadi andalan keluarga kurang mampu di daerah penelitian adalah melalui kelembagaan Arisan dan Perkumpulan sosial-keagamaan.

\section{Rekomendasi}

Berdasarkan hasil penelitian, saran-saran yang bisa dikemukakan adalah sebagai berikut :

1. Untuk meningkatkan kapasitas usaha rumah tangga kurang mampu diperlukan adanya lembaga pembiayaan yang merupakan pengembangan dari sistem arisan yang ada. Lembaga ini disebut Arisan Plus yaitu sistem arisan yang anggotanya bisa memperoleh tambahan 
modal melalui undian (sebagaimana sistem arisan tradisional), juga bisa memperoleh pinjaman modal dari dana kumpulan anggota arisan tersebut.

2. Guna memperluas kesempatan kerja di kawasan wisata, lembaga yang terbentuk disamping mempunyai unit kegiatan pembiayaan, juga dikembangkan menjadi lembaga pelatihan pengembangan kewirausahaan dan bisnis yang sesuai dengan bidang usaha, dan terbuka bagi anggota keluarga rumah tangga miskin. Peningkatan kapasitas usaha dan ketrampilan akan memperkuat posisi tawar rumah tangga kurang mampu dalam menghadapi dinamika industri pariwisata yang semakin modern.

\section{DAFTAR PUSTAKA}

Ashley, Caroline (2000), The Impact of Tourism on Rural Livelihoods:Namibia's Experience, ODI Working Paper no. 128. London, ODI.

Bourdieu, P, 1996, "The forms of capital. In J. Richardson (Ed). Handbook of Theory and Research for Socioloty of Education “, pp241 -580), New York: Greenwood Press.

Cattarinich, Xavier (2001), Pro-poor Tourism Initiatives in Developing Countries : Analysis of secondary case studies, PPT Working Paper No. 8, Department of Sociology, University of Alberta, Canada

Coleman, J.S, 1988, Social Capital in The Creation of Human Capital”, The American Journal of Socioloty: 94 (Supplement): S95 - S120.

1990, "Foundations of Social Theory " Cambridge, Mass : Harvard Univeristy Press.

Damanik, Janianton (2005), Penanggulangan Kemiskinan Melalui Pariwisata, Yogyakarta, Kepel Press

Francois, P, 2002, "Social Capital and Economic Development”, London : Routledge.

Fukuyama, Francis, 1998, "The End of History and The Last Man (Introduction Reproduced 2005)”, Penguin.

2002, "Social Capital and Development: The Coming Agenda", SAIS Review XXII (1) : $23-37$.

Jackson. Leonard. A. (2006). Ameliorating The Negative Impact of Tourism: a Caribbean Prespective. Journal International of Contemporary Hospitality Management. 18(7): 574-582

Manenta, Mara. (2000). Tourism Consumption and Interregional Economic Impact in Italy. Journal International of Contemporary Hospitality Management. 12(7): 417-423

Mulyaningrum. (2005). Eksternalitas Ekonomi Dalam Pembangunan Wisata Alam Berkelanjutan (Studi Kasus Pada Kawasan Wisata Alam Baturaden-Purwokerto, Kabupaten Banyumas Propemsi Jawa Tengah. Jurnal Penelitian UNIB. 11(1):9-20

Shuib, A. Wan, S.W.M., Abdullah. M., Zahid, E. 1986, The Local Economic Impact of The Development of Taman Negara Malaysia. Didalam B. Stecker. 1986. Ecotourism: Potential for Conservation and Sustainable Use of Topical Forest. Eschom: Deutsche Gesellschaft furTechnische Zusammenarbeit (GTZ) GmbH

Sudiarditha, I.K,. Suman, A, dan Kusnadi. 2001. Analisis Pengembangan Sektor Industri Pariwisata Terhadap Penyerapan Tenaga Kerja Dan Pendapatan Rumah Tangga Petani. Jurnal Wacana. 


\section{Journal of Indonesian Applied Economics}

Vol. 3 No. 1 Mei 2009, 10-22

$3(2): 125-133$

Spillane, J.J. 2001. Ekonomi Pariwisata: Jakarta. Penerbit Kanisius.

Tjokrowinoto, dan Muljarto. 2004, Pengurangan Kemiskinan Melalui Pariwisata : Perspektif Kebijakan Publik. Makalah dalam Pertemuan Nasional Koordinasi Kebijakan Penanggulangan Kemiskinan Melalui Pariwisata: Jakarta. Kementrian Koordinasi Kesejahteraan Rakyat 